\title{
Climatic trends in continental shelf waters off Ghana and in the Gulf of Guinea, 1963-1992
}

\author{
Kwame A. KORANTENG ${ }^{a *}$, Jacqueline M. MCGLADE ${ }^{\mathrm{b}}$ \\ ${ }^{a}$ Marine Fisheries Research Division, P.O. Box BT-62, Tema, Ghana \\ ${ }^{\mathrm{b}}$ Ecosystems Analysis and Management Group, University of Warwick, Coventry, UK
}

Received 17 July 2000; revised 20 November 2000; accepted 22 November 2000

\begin{abstract}
Using time series analyses, some physical parameters of the continental shelf waters of the Gulf of Guinea were examined. Analysis of coastal sea surface temperatures from Ghana and Ivory Coast, and offshore sea surface temperatures from the Gulf of Guinea clearly shows spatial and inter-annual patterns of cooling in coastal waters of West Africa. The behaviour of the decomposed trend of coastal and offshore sea surface temperatures, sub-surface temperature measured at $100 \mathrm{~m}$ depth off Ghana and salinity showed that the observational period (1963-1992) could be divided into three climatic periods: the period before 1972, from 1972 to 1982, and the period after 1982. In the first period, sea surface temperature at both coastal and offshore areas and bottom temperature declined and coastal salinity was relatively low. The second period was a cold one with less than average sea surface and sea bottom temperatures. The mixed layer was narrow with the thermocline remaining shallower than its long-term average position. Coastal and bottom salinity (measured at the $100 \mathrm{~m}$ depth) were relatively high but the seasonal variation was minimal. This period of significant change in the physical components of the ecosystem of the Ghanaian shelf waters has hitherto not been documented in the literature. In the final phase, temperatures were high, and salinity was low and erratic. The observed localised environmental changes are consistent with global changes in the Gulf of Guinea and possibly in the tropical Atlantic basin. () 2001 Ifremer/CNRS/IRD/Éditions scientifiques et médicales Elsevier SAS
\end{abstract}

Résumé - Évolution climatique à long terme du plateau continental du Ghana et du golfe de Guinée 1963-1992. Les résultats d'une analyse de séries temporelles de paramètres de l'environnement du plateau continental du golfe de Guinée sont présentés. Une analyse de la température de surface côtière illustre les types de variabilité spatio-temporelle dans cette région. La température côtière, la température au large, ainsi que la température et la salinité de sub-surface (100 m) devant le Ghana montrent que la période 1963-1992 peut être divisée en trois épisodes : avant 1972, de 1972 à 1982 et après 1982. Dans la première période, la température de surface, tant à la côte qu'au large, ainsi que la température sur le fond se refroidissent, la salinité côtière restant basse. La seconde période est une période froide, caractérisée par des anomalies négatives de la température de surface et de fond. La couche de mélange est réduite et la thermocline se situe à une profondeur moindre que celle de la moyenne «climatique ». La température côtière et la salinité sur le fond $(100 \mathrm{~m})$ sont relativement élevées mais l'amplitude des variations saisonnières est minimale. Cette période de changements de l'écosystème du Ghana n'avait pas été décrite jusqu'à présent. Dans la dernière phase, les températures sont élevées et la salinité basse, avec un comportement irrégulier. Les changements observés sont cohérents avec les changements globaux dans le golfe de Guinée et dans l'Atlantique Sud. @ 2001 Ifremer/CNRS/IRD/Éditions scientifiques et médicales Elsevier SAS

marine environment / West Africa / time series

environnement marin / Afrique de l'Ouest / séries temporelles

*Correspondence and reprints: fax:+233 22203066.

E-mail address: kwamek@africaonline.com.gh (K.A. KORANTENG).

(C) 2001 Ifremer/CNRS/IRD/Éditions scientifiques et médicales Elsevier SAS. Tous droits réservés 


\section{INTRODUCTION}

Situated between the Canary Current and the Benguela Current to the north and south respectively, the Guinea Current marine ecosystem extends from Bissagos Islands (approximately latitude $11^{\circ} \mathrm{N}$, longitude $16^{\circ} \mathrm{W}$ ) to Cape Lopez (latitude $0^{\circ} 41^{\prime} \mathrm{S}$, longitude $8^{\circ} 45^{\prime} \mathrm{E}$ ) (Binet and Marchal, 1993) (figure 1). It includes the maritime waters of all countries between Guinea Bissau and Gabon in West Africa. Off Ghana and Ivory Coast in the central part of the large marine ecosystem, two upwelling seasons, major and minor, occur annually with differing duration and intensities (Longhurst, 1962; FRU/Orstom, 1976).

Small pelagic fisheries in the area are sustained by these seasonal upwellings (FRU/Orstom, 1976; Mendelssohn and Cury, 1987; Pezennec and Koranteng, 1998). From about 1972, there have been remarkable changes in the distribution, abundance and reproductive strategy of the round sardinella (Sardinella aurita Clupeidae) in this ecosystem (Pezennec, 1994; Quaatey and Maravelias, 1999). In the same period, there were significant changes in the abundance of some demersal fish in the Gulf of Guinea. For example, between 1973 and 1979, there was a phenomenal increase in the population of triggerfish (Balistes capriscus Balistidae) in the sub-region (AnsaEmmim, 1979; Caverivière, 1991). The species dominated this ecosystem and at some point, accounted for over $60 \%$ of total fish biomass assessed in bottom trawl surveys (Koranteng, 1984) and about $83 \%$ of total pelagic biomass assessed in acoustic surveys (Stromme, 1983).

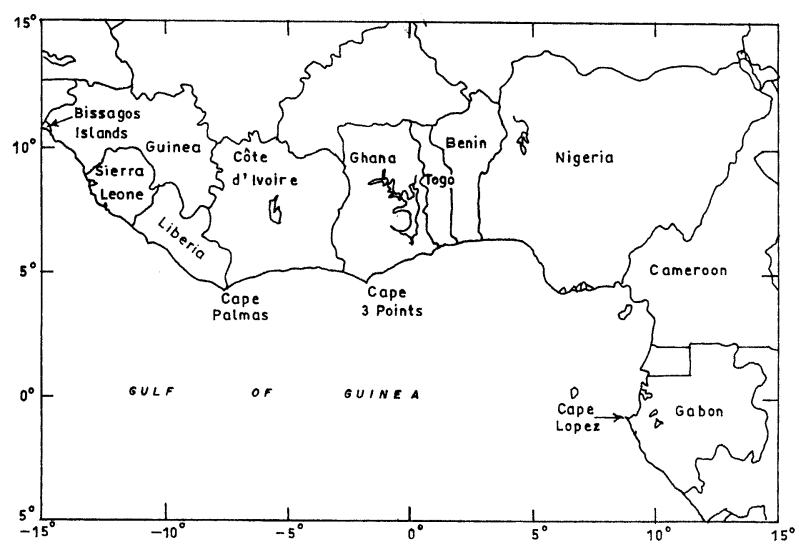

Figure 1. Map of West Africa showing areas and landmarks mentioned in the text.
These changes have been attributed mainly to environmental factors, especially intensification of the minor upwelling, changes in salinity regime of the area and fishing intensity (Pezennec and Bard, 1992; Pezennec, 1994; Koranteng, 1998; Pezennec and Koranteng, 1998).

The coastal hydrography of the Gulf of Guinea is generally divided into four regimes: a short cold season in December-January (minor upwelling), a long warm season between February and June, a long cold season between July and September (major upwelling) and a short warm season in October-November (Longhurst, 1962). In the major upwelling season, sea surface temperatures $(S S T)$, which are usually about $27-29^{\circ} \mathrm{C}$ fall below $25^{\circ} \mathrm{C}$, surface salinities increase, and dissolved oxygen values generally fall. The driving mechanisms of the upwelling in the western Gulf of Guinea are not well understood. However, the numerous studies on the system have shown that it is not of the classical winddriven, Ekman type that characterizes other eastern boundary upwelling ecosystems (Houghton, 1976; Bakun, 1978).

The cause of the upwelling off Ghana and Ivory Coast has at one time or the other been attributed to evaporation (Pople and Mensah, 1971), eastward current (Marchal and Picaut, 1977; Bakun, 1978), and remote forcing by coastally trapped Kelvin waves (Moore et al., 1978; Servain et al., 1982). Examining each of these hypotheses in detail, Roy (1995) concluded that the upwelling off Ghana and Ivory Coast may be caused by a combination of factors, but singled out wind as a possible prominent factor in the case of the minor upwelling. In this paper we examine the nature and extent of change in the marine environmental conditions off Ghana and Ivory Coast, and we compare some of the observed changes to the situation in other parts of the Gulf of Guinea and the western part of the southern Atlantic Ocean. We then attempt to relate the observed environmental changes to changes in some fishery resources of the sub-region.

\section{MATERIALS AND METHODS}

The data sets used in this work were obtained mainly from the Marine Fisheries Research Division (Fisheries Department, Ghana). These are as follows: 
- daily sea surface temperature (SST) recorded at five locations along the Ghanaian coastline for the period 1963-1992,

- coastal salinity recorded daily off Tema (Ghana), 1970-1992,

- temperature and salinity recorded weekly at $100 \mathrm{~m}$ depth on a hydrographic transect located off Tema, Ghana, 1968-1992,

- temperature recorded at the surface, 10, 20, 30, 40, 75 and $100 \mathrm{~m}$ depth on the hydographic transect off Tema, 1968-1992,

- offshore SSTs compiled from the Comprehensive Ocean Atmosphere Data Sets (COADS) (Woodruff et al., 1987), 1946-1992.

The coastal stations are Keta, Tema, Takoradi, Cape Three Points and Axim (figure 2). Sub-sets of the COADS data were extracted using the CODE computer program (Mendelssohn and Roy, 1996). Data were extracted for four areas off Ivory Coast-Ghana (i.e. between latitudes 1 and $6^{\circ} \mathrm{N}$, and from longitude $7^{\circ} \mathrm{W}$ to $1^{\circ} \mathrm{E}$ ) (figure 2).

A time series of monthly means was constructed for each environmental parameter. The monthly averages were calculated from daily records. Each missing value in the daily records was replaced with the average of the preceding and ensuing days. Where there were no records at the station for the whole month, an average of the preceding and ensuing months was used. A two-way

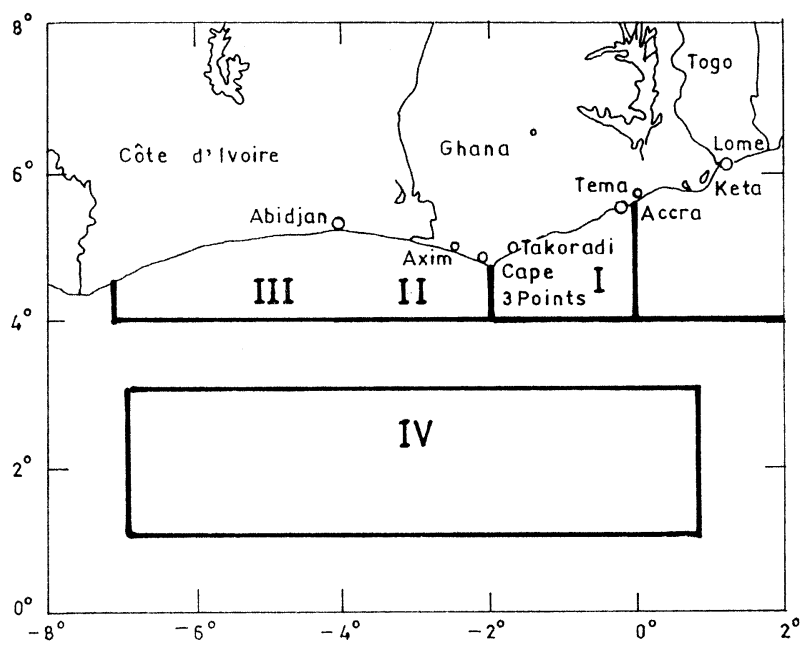

Figure 2. Areas off Ghana and Ivory Coast for which data were extracted from the comprehensive ocean-atmosphere data set. The coastal stations in Ghana are also shown. (coastal station/year) spatial plot of SST was produced. The time series data of each environmental parameter was then decomposed using a model of the form

$$
Y i=T i+S i+R i
$$

where $Y i$ represent the observed data (e.g. $S S T), T i$ is the trend, $S i$ is the seasonal variation and $R i$ represents the remainder random elements of the series after the trend and seasonal variation have been accounted for. The analysis was carried out using the STL routine incorporated in the S-PLUS computer software (MathSoft, 1995). "STL is a Seasonal-Trend decomposition procedure consisting of a sequence of smoothing operations that employ locally weighted regression or Loess" (Cleveland et al., 1990). In the estimation procedure, the set of values for each month of the year is treated as a sub-series. The output is composed of an inter-annual component common to all the sub-series, a seasonal component and a residual component. A detailed mathematical treatise of the method may be found in Cleveland et al. (1990).

Standardized anomalies of the monthly means of each environmental parameter (e.g. SST) were calculated from:

$$
X_{j}=\frac{r_{j}-\bar{r}}{s}
$$

where $r_{j}$ is the monthly mean value of the parameter, and $\bar{r}$ and $s$ are the mean and standard deviation respectively of the series. Such anomalies are distributed with a zero mean and a variance of one. Where there were more than one series of the same parameter (e.g. the coastal SSTs) a combined anomaly was calculated from:

$$
X_{j}=\frac{1}{N_{j}} \sum_{i=1}^{N_{j}} \frac{r_{i j}-\bar{r}_{i}}{s_{i}}
$$

where $r_{i j}$ is the mean of the parameter for year $j$ at station $i, \bar{r}_{i}$ and $s_{i}$ are the mean and standard deviation respectively of the $i$ th staition's series, and $N_{j}$ is the number of stations with complete records in year $j$. Thus information from all the stations was combined in this index. Statistical properties of such an index are have been examined (Kraus, 1997). A 13-point moving average was applied as a low-pass filter to remove the seasonal variation in the time series of anomalies (Chatfield, 1996).

From the temperature values recorded weekly at the specified depths on a reference hydrographic transect off 
Tema (Ghana) (Koranteng, 1998), monthly and annual mean depth of the thermocline, represented by the depth of the $21^{\circ} \mathrm{C}$ isotherm (Merle, 1978; Koranteng and Pezennec, 1998) were calculated.

Preliminary results of the analyses showed that between 1963 and 1992, there were distinct climatic periods within each of which environmental conditions were different. To clearly identify the climatic periods, new temperature and salinity anomalies were calculated using the monthly mean values of the decomposed trend of each series as the data values.

\section{RESULTS}

Annual means of temperature and salinity measured off Tema (Ghana) are presented in table I. Both surface (measured at the coastal station) and bottom (measured at $100 \mathrm{~m}$ depth on the Tema hydrographic transect) are given. The plot of annual means of SST at the coastal stations (figure 3) shows the spatial differences in cooling between Keta on the east and Axim on the west with the area off Takoradi (i.e. east of Cape Three Points) experiencing more intense cooling than the rest of the littoral. Plots of the standardized SST anomalies for the five coastal stations were produced. Except for minor differences, especially with regard to the Axim series, the five series exhibited similar tendencies with relatively cold and warm years occurring around the same period. Approximately three $S S T$ regimes are identifiable from figure 4 as follows:

- Regime 1 (1963-1974): SST are unsettled and the moving average alternates in its position around the mean.

- Regime 2 (1975-1980): the moving average remains below the zero line longer than any period in the series. These are relatively cold years.

- Regime 3 (1981-1992): SST are unsettled initially but the anomalies generally remain positive towards the end of this period.

Figure 5 shows the extracted trend and seasonal variation of the coastal SST series recorded at Tema in Ghana. The plot of the trend component shows a period of declining temperatures between 1963 and 1976 and a second period of rising temperatures between 1977 and 1992. Linear regression of the derived trend values (for the Tema series) versus time (years) show that both the fall (signifying cooling) and rise (warming) of temperature were
Table I. Mean values of temperature and salinity measured at $100 \mathrm{~m}$ depth off Tema, Ghana.

\begin{tabular}{|c|c|c|c|c|}
\hline \multirow[t]{2}{*}{ Year } & \multicolumn{2}{|c|}{ Temperature } & \multicolumn{2}{|l|}{ Salinity } \\
\hline & $\begin{array}{l}\text { Surface } \\
\text { (coastal) }\end{array}$ & Bottom & $\begin{array}{l}\text { Surface } \\
\text { (coastal) }\end{array}$ & Bottom \\
\hline 1963 & 26.6 & & & \\
\hline 1964 & 25.3 & & & \\
\hline 1965 & 26.2 & & & \\
\hline 1966 & 26.0 & & & \\
\hline 1967 & 25.0 & & & \\
\hline 1968 & 26.7 & 16.6 & & 35.60 \\
\hline 1969 & 26.0 & 16.8 & & 35.26 \\
\hline 1970 & 26.2 & 16.7 & 34.83 & 35.57 \\
\hline 1971 & 25.8 & 16.8 & 35.22 & 35.74 \\
\hline 1972 & 25.9 & 16.3 & 35.36 & 35.74 \\
\hline 1973 & 26.4 & 16.7 & 35.33 & 35.56 \\
\hline 1974 & 26.0 & 16.2 & 35.25 & 35.70 \\
\hline 1975 & 25.7 & 16.0 & 35.22 & 35.66 \\
\hline 1976 & 25.1 & 15.9 & 35.51 & 35.73 \\
\hline 1977 & 25.3 & 16.2 & 35.44 & 35.75 \\
\hline 1978 & 25.7 & 16.3 & 35.33 & 35.83 \\
\hline 1979 & 26.5 & 17.2 & 35.28 & 35.87 \\
\hline 1980 & 26.0 & 16.5 & 35.25 & 35.78 \\
\hline 1981 & 26.5 & 16.3 & 34.8 & 35.81 \\
\hline 1982 & 25.8 & 16.9 & 35.25 & 35.86 \\
\hline 1983 & 25.4 & 16.8 & 35.09 & 35.64 \\
\hline 1984 & 26.4 & 17.0 & 34.98 & 35.68 \\
\hline 1985 & 25.8 & 16.7 & 35.21 & 35.66 \\
\hline 1986 & 25.4 & 16.6 & 35.16 & 35.36 \\
\hline 1987 & 27.0 & 16.8 & 35.17 & 35.80 \\
\hline 1988 & 26.5 & 17.2 & 35.22 & 35.52 \\
\hline 1989 & 26.3 & 17.1 & 34.87 & 35.43 \\
\hline 1990 & 25.9 & 17.0 & 35.46 & 35.79 \\
\hline 1991 & 26.1 & 17.3 & 35.17 & 35.65 \\
\hline 1992 & 26.1 & 17.2 & 35.18 & 35.63 \\
\hline
\end{tabular}

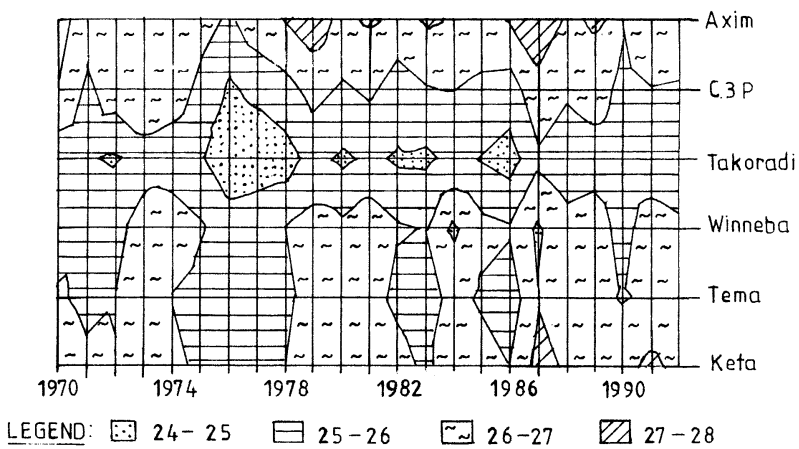

Figure 3. A two-way plot of annual mean sea surface temperature recorded at indicated coastal stations off Ghana. 


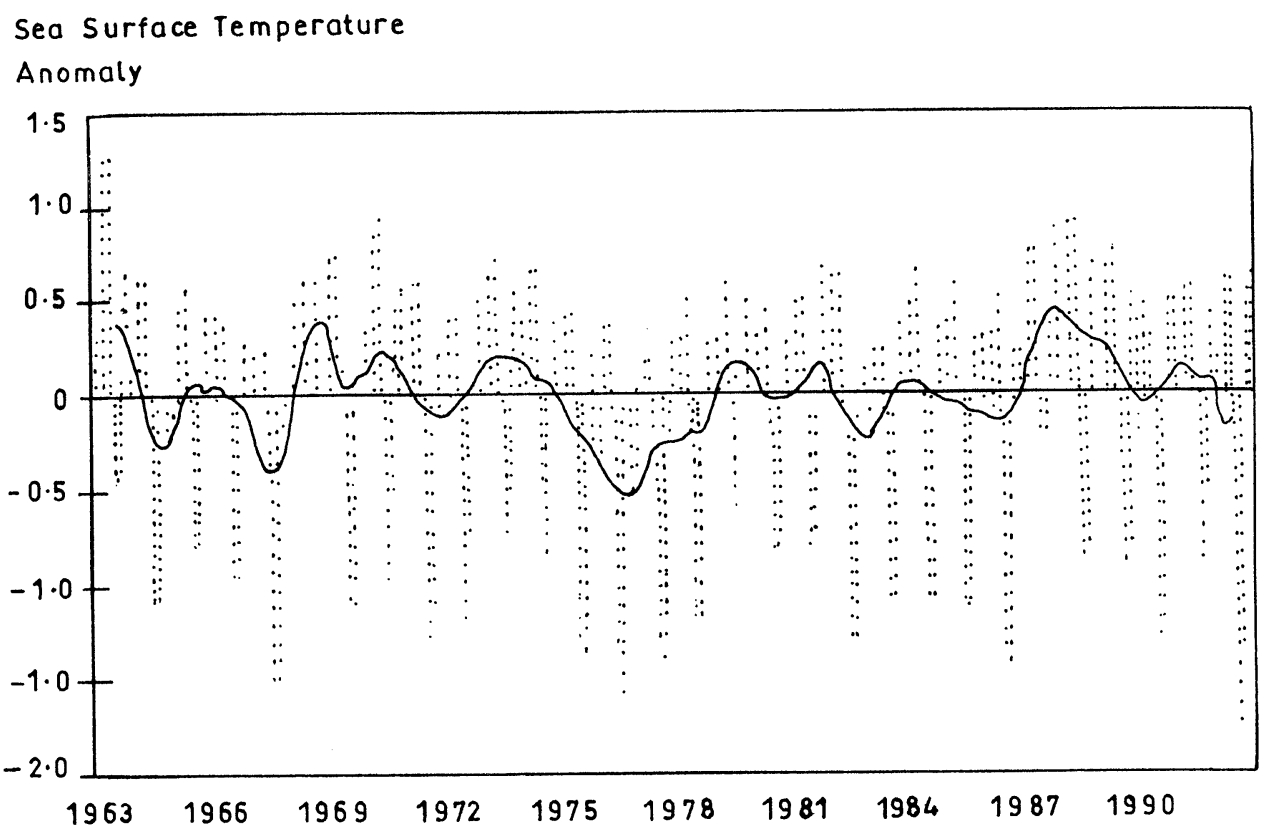

Figure 4. Mean sea surface temperature anomaly calculated from data collected at five coastal stations in Ghana.

highly significant $(P<0.001)$. The trend component of the SST series of the other coastal stations follow a similar pattern (figure 6). The trend of the COADS SST series (figure 7) also exhibits periods of cooling and warming.

From the plot of the seasonal component of each series (e.g. figure 5) it is possible to follow the intra-annual (seasonal) variation in sea surface cooling. Within each year, the lowest point on the graph corresponds to the peak of cooling (major upwelling) and the highest point corresponds to the peak of warming. Between these are points corresponding to the first cold period in the year (January/February) and the warm period towards the end of the year (October/November).

The trend and seasonal components of the mean monthly temperature measured at the $100 \mathrm{~m}$ depth off Tema are presented in figure 8. The first figure shows that the bottom temperature exhibited almost the same pattern of change as has been described for the coastal SST. The seasonal component of the series reveals much more information about the strength of the upwelling over time than the coastal SST series.

The trend of the Tema coastal sea surface salinity (figure 9) shows a period (1970 and 1978) of increasing or high salinity (up to about 35.45), a period (1978 and 1982) of rapid reduction of salinity, and a period (1982 and 1992) of relatively stable salinity of around 35.2. The striking feature of the salinity series is the decline (in the first period) and rise (in the second period) in amplitude of the seasonal component (figure 9).

Using the extracted trend values as data values in the calculation of anomalies, the resultant anomalies of temperature and salinity (both at the surface and bottom of the sea) are shown in figure 10. The figures show that the period under consideration was clearly divided into three regimes, namely the period until 1972, 1972-1982 and 1982-1992 (using the mean values).

During the period of investigation, the $21{ }^{\circ} \mathrm{C}$ isotherm (used here to represent the depth of the thermocline) was encountered on the Tema transect at depths from just below the surface to over $100 \mathrm{~m}$ deep (Koranteng, 1998). The author also showed that the annual mean thermocline depth generally reduced between 1968 and 1975 where the smallest annual mean depth $(29.4 \mathrm{~m})$ was calculated. The largest annual mean depth $(51 \mathrm{~m})$ was in 1978 and the long-term annual mean depth was $41 \mathrm{~m}$. 


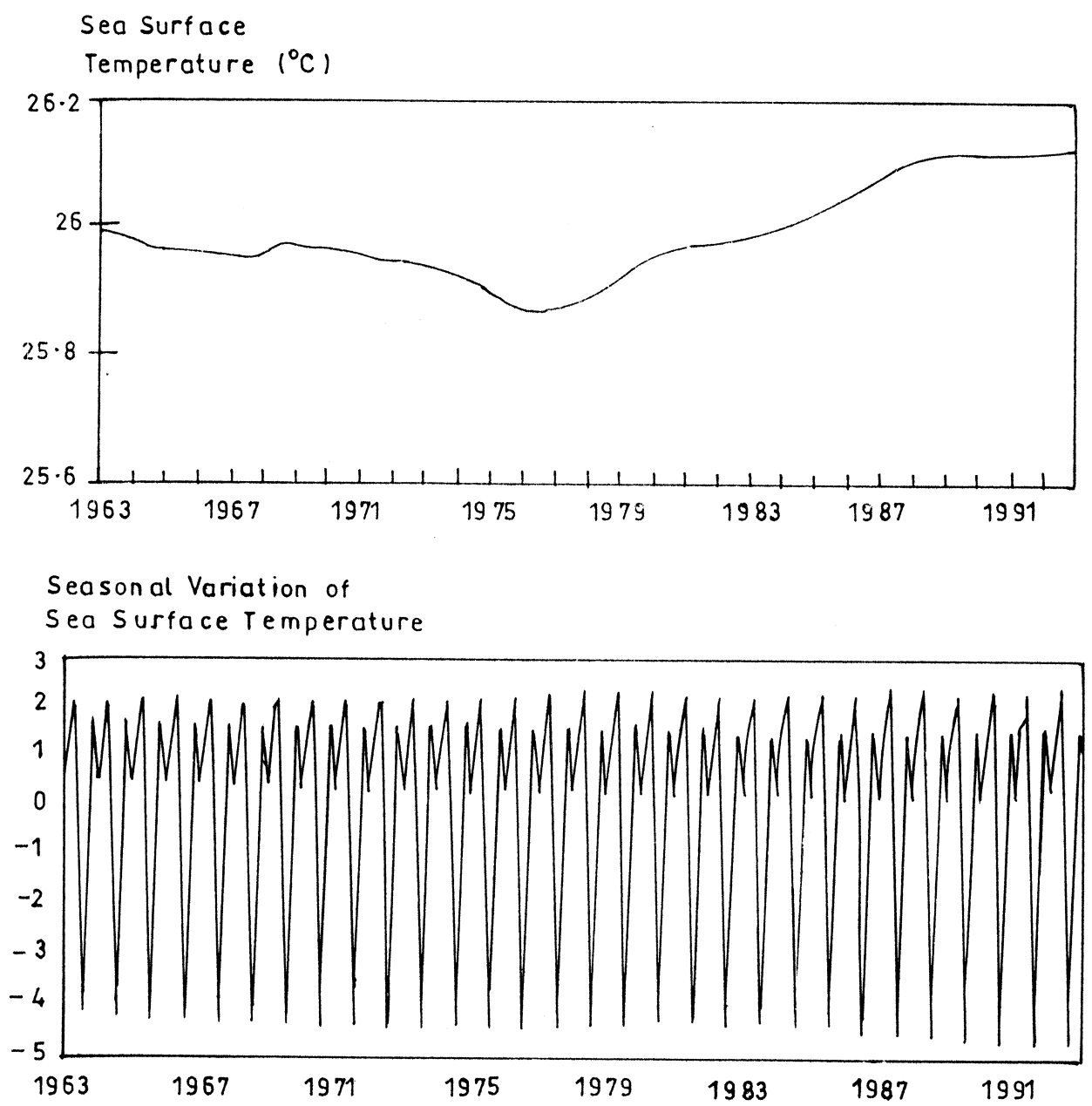

Figure 5. Trend and seasonal variation of a series of sea surface temperature measured at Tema, Ghana.

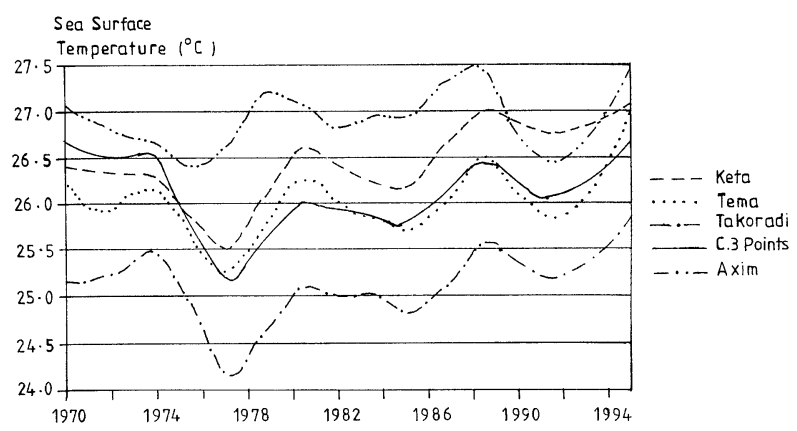

Figure 6. Trends of time series of sea surface temperature measured at five coastal stations in Ghana.

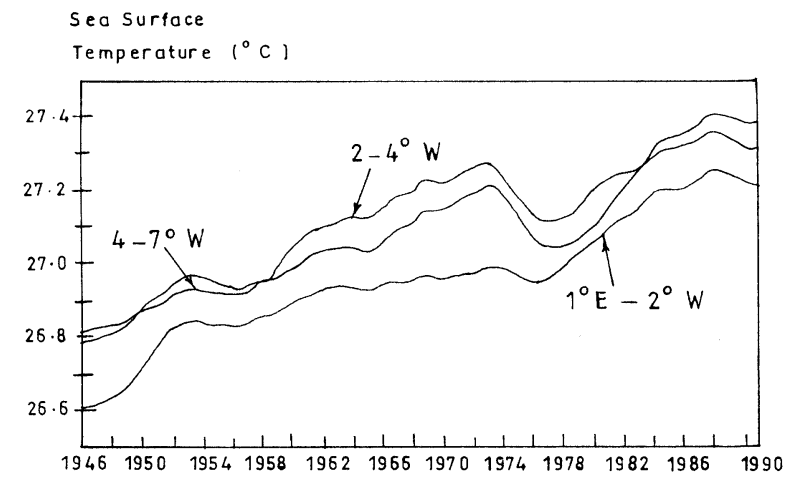

Figure 7. Trend of offshore sea surface temperature extracted from the comprehensive ocean-atmosphere data set for three areas off Ghana and Ivory Coast. 
Temperature

At $100 \mathrm{~m}$ Depth $\left({ }^{\circ} \mathrm{C}\right)$

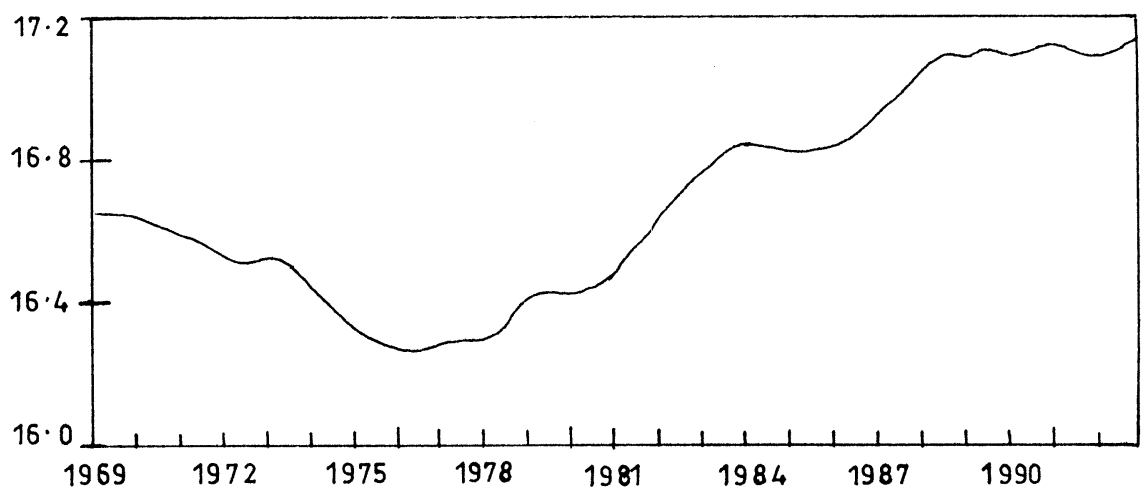

Seasonal Variation of Temperature At $100 \mathrm{~m}$ Depth

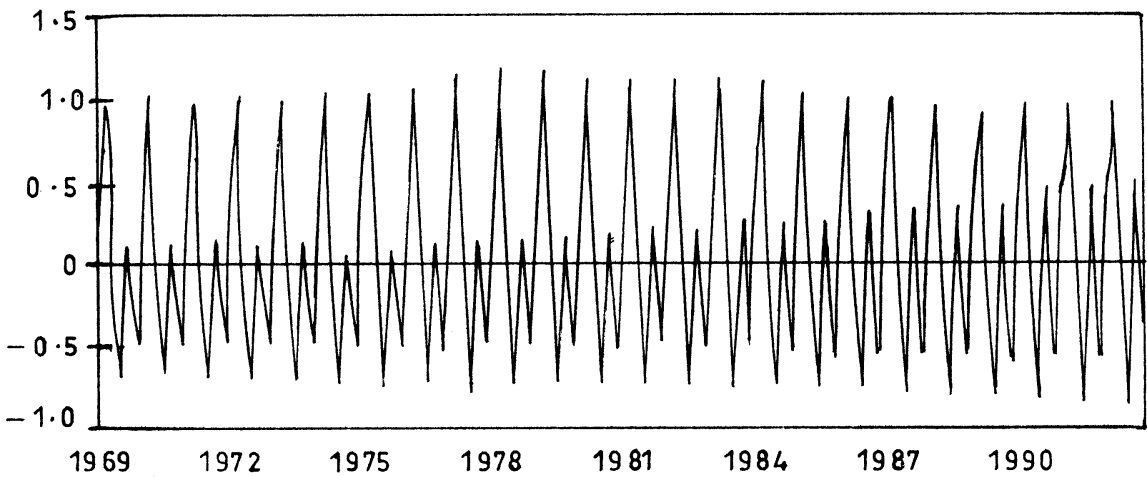

Figure 8. Trend and seasonal variation of temperatures recorded at $100 \mathrm{~m}$ depth off Tema, Ghana.

\section{DISCUSSION}

Throughout the observational period, relatively low temperatures were recorded in the area around Takoradi (figure 3). This figure also shows periods of intense cooling within the 23-year period of investigation. The period of sustained cold water between 1975 and 1979 is evident from the figure. During these years, the cooling was experienced along the entire coastline. The figure also shows other, but relatively shorter, periods of cooling that occurred mainly off Takoradi.

The periods of decline of the coastal SST, from the $1960 \mathrm{~s}$ to the mid-1970s, and a subsequent rise, are in phase with the behaviour of the COADS SST series (figure 7). The latter series shows a general underlying increase in sea surface temperature since 1946 with some decline in 1954-55, 1964-65, 1975-76 and 1987-88. Thus the changes appear to be decadal in nature. The decline in 1975-76 was most pronounced within the 47-year period, and this was picked up in the coastal and bottom temperature series recorded in Ghana's continental shelf waters.

Also evident from the plot of the seasonal component of the Tema SST and sub-surface temperature series (figures 5 and 8 respectively) are:

- consistently increasing temperatures during the second warm season (i.e. October/November) between 1975 and 1992,

- general reduction of temperatures during the minor upwelling period (January/February) signifying an intensification of this upwelling,

- slight increase in temperatures during the main warm season (April/June) signifying intensification of warming. 


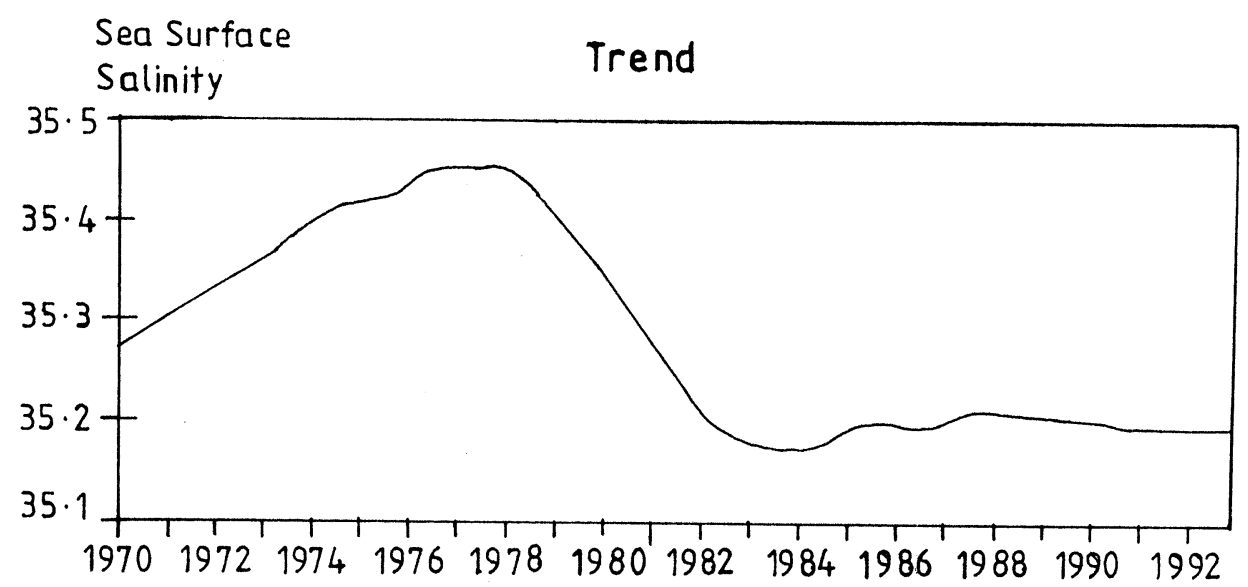

Seasonal variation

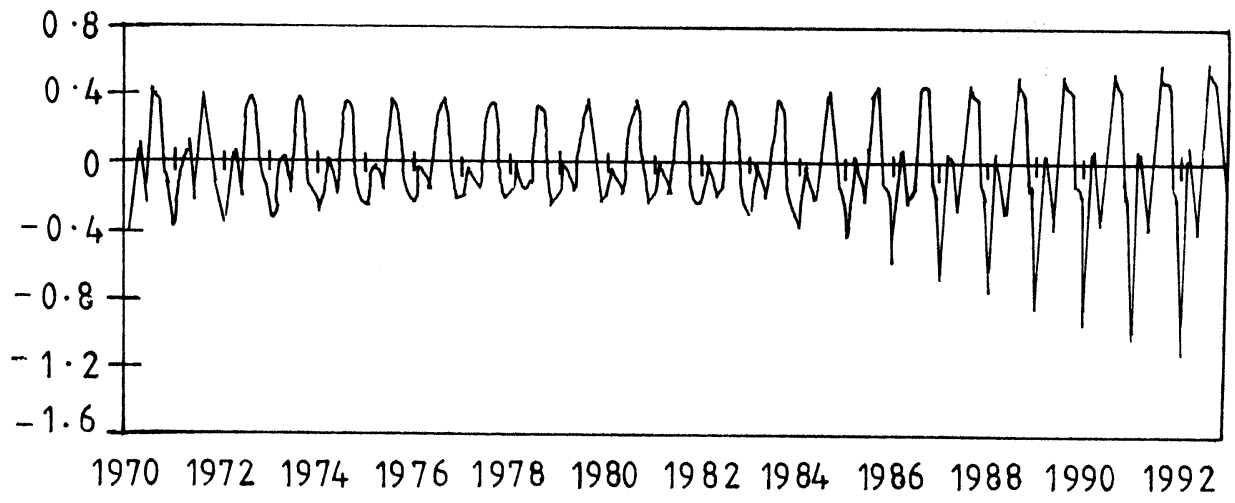

Figure 9. Trend and seasonal variation of coastal salinity measured off Tema, Ghana.

These features are more pronounced in the sub-surface temperature series than the SSTs and it appears that the overall increase in oceanic water temperature in the study area may be due mainly to the warming at the end of the year. From changes in upwelling indices, similar conclusions, especially as regards intensification of the minor upwelling, were reached (Arfi et al., 1991; Pezennec and Bard, 1992; Koranteng and Pezennec, 1998). However, these events have been picked up more clearly in the time series decomposition analysis than from the use of upwelling indices. The change in seasonal variation is not very evident from the COADS series, implying less significant change in the intensity of the two upwelling events in offshore areas. This is understandable as the upwelling in the western Gulf of Guinea is coastal.

The re-calculated trend anomalies (figure 10) clearly divide the period under consideration into three regimes, namely the period until 1972, 1972-1982 and 1982-1992. These are hereafter referred to as climatic periods. In the first climatic period, surface (both coastal and offshore) and sub-surface temperature declined and coastal salinity was relatively low. The second climatic period was a cold one with less than average temperatures. The mixed layer was narrow with the thermocline remaining shallower than its long-term average position. Coastal and bottom salinity (measured at the $100 \mathrm{~m}$ depth) were relatively high but the seasonal variation was minimal. In the final climatic period, temperatures were high and salinity was low and erratic.

Figure 11 gives trends of SST obtained from COADS for the areas off Sierra Leone-Liberia and Nigeria-Cameroon to the northwest and southeast respectively of the Ivory Coast-Ghana area. The figure also shows periods of decline of temperatures (between 1970 and 1982) and 


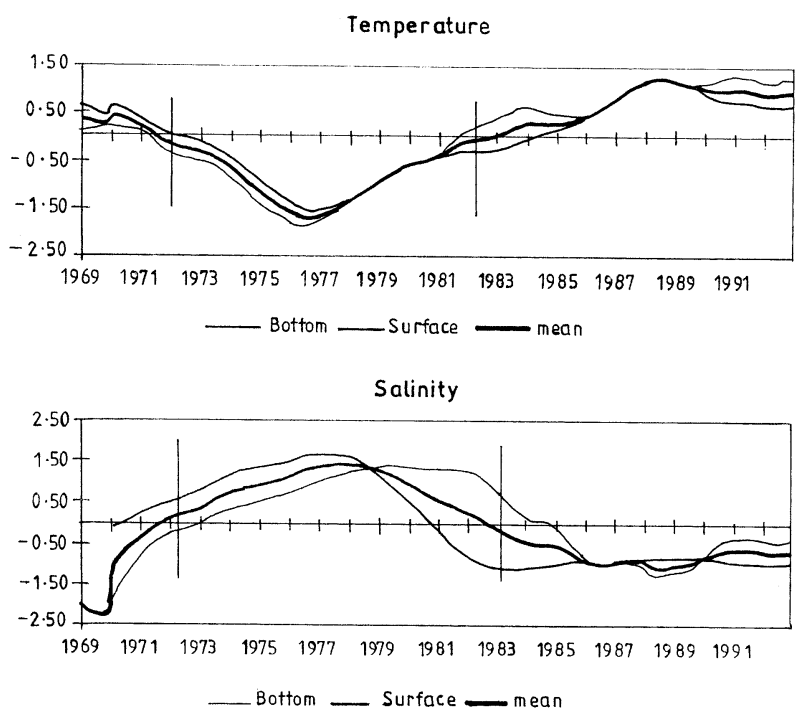

Figure 10. Climatic periods of temperature and salinity in the Gulf of Guinea. Plots were obtained from calculating temperature and salinity anomalies using extracted trend values as the data.

rising temperature from 1982. The behaviour of these SST trends is in agreement with the situation off Ghana. There appears to be a 2-3 year time lag between the Sierra Leone-Liberia and Nigeria-Cameroon series.

Links between standardized anomalies of SST measured at Tema, Ghana $\left(05^{\circ} \mathrm{N}, 00^{\circ} 04^{\prime} \mathrm{E}\right)$ and at Cananeia (south of Sao Paulo) in Brazil $\left(25^{\circ} \mathrm{S}, 47^{\circ} 55^{\prime} \mathrm{W}\right)$ have been shown (Koranteng, 1998). The author showed that similar specific cold and warm events existed in the two series with the Tema series usually lagging behind the Cananeia series. For example, the sustained low SST that occurred off Tema between 1975 and 1978 were also seen in the Cananeia series but for 1973-1976. Similarly, the warm events of 1987-1989 off Tema occurred during 1985-1987 off Cananeia.

These observations suggest that the specific environmental changes observed in continental shelf waters of Ghana-Ivory Coast in the western Gulf of Guinea, as described in this paper, could be generalised for the whole Gulf of Guinea and possibly for the whole southern Atlantic basin but some more analyses may be required to confirm this. However, interconnections between the western and eastern parts of the Atlantic Ocean have been noted in the past. For example, eastward movement of positive SST anomalies from the Brazilian coast towards the Angolan and Namibian coasts during the 1984 warm events in the Atlantic were noted (Hisard, 1988).

The literature is quite clear on the warm climatic events that occurred in the Atlantic over the last three decades and attempts to draw a parallel with El Niño-Southern Oscillation events in the Pacific (Shannon et al., 1986; Bakun, 1996). On the contrary, the cold period of 1975-1979, as identified here, has hitherto, not been seriously discussed in the literature even though it has been identified in the plots of some papers, e.g. Arfi et al. (1991) and Binet (1997).

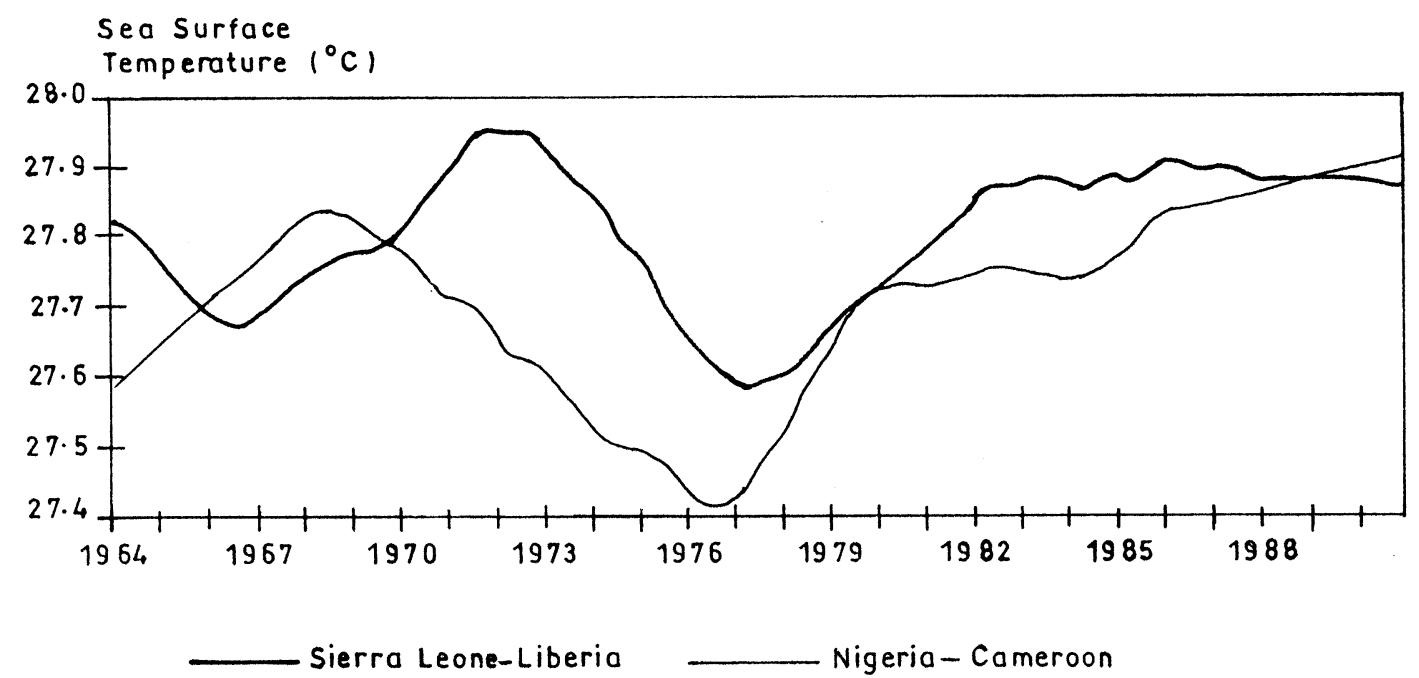

Figure 11. Sea surface temperature trends in areas to the northwest (Sierra Leone-Liberia) and southeast (Nigeria-Cameroon) of Ghana. 
Perturbations in the aquatic environment could have significant impacts on the behaviour of some species of fish (Margalef, 1988; Baird et al., 1991). For example, the effects of such environmental changes on the growth, distribution and abundance of Sardinella aurita in the western Gulf of Guinea have been noted (Pezennec and Bard, 1992; Pezennec, 1994; Pezennec and Koranteng, 1998). There is also a remarkable synchrony between the climatic periods identified in this paper and the events that have occurred in the round sardinella (Sardinella aurita) and triggerfish (Balistes capriscus) fisheries in continental shelf waters of the western Gulf of Guinea.

In the case of the round sardinella, the environmental regimes closely match the relatively 'healthy' phase of the stock before the high landings of 1972; the 'collapsed' phase between 1973 and 1982 and the recovered or 'prosperous' phase between 1983 and 1992 (Pezennec, 1994). Total landings of the species by Ghanaian and Ivorian vessels fishing in the western Gulf of Guinea are presented in table II for the period 1966-1992. Except in 1968, high landings were recorded between 1966 and 1972; nearly $95000 \mathrm{t}$ was landed in 1972 compared to an annual landing of between 8000 and $48000 \mathrm{t}$ in the period. In the ensuing years (1973-1982) landings were low, especially in the first 5 years. From 1983, high landings were recorded again culminating in the all-time high landing of about $154000 \mathrm{t}$ in 1992 (Bard and Koranteng, 1995).

The environmental regimes also match the years of appearance and disappearance of Balistes capriscus in this ecosystem. Proliferation of the species started around 1972-1973 (Ansa-Emmim, 1979) and flourished in the mid-to-late 1970s until late 1980s (i.e. during the second climatic period). Its decline was observed after 1982 (i.e. during the third climatic period) (Pezennec, 1994; Koranteng, 1998). Table III shows biomass of the species assessed in bottom trawl surveys conducted in Ghanaian waters between 1963 and 1990. The biomass was low in the first period, high in the second and declined again in the third period. Calculated density (in tons per square nautical mile, $\mathrm{t} \mathrm{NM}^{-2}$ ) for each of the climatic periods is also shown in the table. The density of the species increased from $0.30 \mathrm{t} \mathrm{NM}^{-2}$ in the first climatic period to $9.62 \mathrm{t} \mathrm{NM}^{-2}$ in 1972-1982, declining thereafter to $0.38 \mathrm{t} \mathrm{NM}^{-2}$ in 1982-1992 (Koranteng, 1998).
Table II. Landings of Sardinella aurita caught in the western Gulf of Guinea by fishing vessels of Ivory Coast and Ghana, 1966-1992.

\begin{tabular}{lc}
\hline Year & Landing $(\mathrm{t})$ \\
\hline 1966 & 15779 \\
1967 & 47222 \\
1968 & 8743 \\
1969 & 29615 \\
1970 & 30411 \\
1971 & 35687 \\
1972 & 94626 \\
1973 & 9169 \\
1974 & 2077 \\
1975 & 2075 \\
1976 & 14852 \\
1977 & 17303 \\
1978 & 50003 \\
1979 & 14563 \\
1980 & 24629 \\
1981 & 25893 \\
1982 & 39392 \\
1983 & 72361 \\
1984 & 57354 \\
1985 & 106364 \\
1986 & 90434 \\
1987 & 82352 \\
1988 & 93175 \\
1989 & 80353 \\
1990 & 61542 \\
1991 & 70373 \\
1992 & 154095 \\
\hline
\end{tabular}

Source: Bard and Koranteng (1995).

Table III. Biomass of triggerfish (Balistes capriscus) in Ghanaian waters assessed through bottom trawl surveys.

\begin{tabular}{lrl}
\hline Survey Period & Biomass $(\mathrm{t})$ & Density for period $\left(\mathrm{t} \mathrm{NM}^{-2}\right)$ \\
\hline $1963-64$ & 330 & \\
$1969-70$ & 1370 & 0.30 \\
$1979-80$ & 40080 & \\
$1981-82$ & 20180 & 9.62 \\
$1987-88$ & 5950 & \\
1989 & 1130 & 0.38 \\
1990 & 440 & \\
\hline
\end{tabular}

Density is expressed in tons per square nautical mile (NM); source: Koranteng (1998)

\section{CONCLUSION}

The period between 1963 and 1992 had within it climatic periods with distinct environmental characteristics in the Gulf of Guinea. In the first climatic period (i.e. before 1972) sea temperatures (surface and bottom) were rela- 
tively high, salinity was low and the thermocline was below its long-term average depth. The second climatic period was characterised by low temperatures and high but stable salinity. The peak of the changing events was between 1975 and 1979. The period was characterised by sustained cold temperatures in the coastal area and offshore. The mixed layer was shallow, due to the persistence of the thermocline at depths shallower than the long-term mean. Coastal (surface) and deep-water (sub-surface) salinities were relatively high, but quite stable in terms of seasonal variation. In the third climatic period, a rising trend in sea surface and bottom temperature was observed. Salinity decreased but was erratic.

These changes appear to have influenced the dynamics of fishery resources in this ecosystem with significant changes in the distribution and abundance of some species coinciding with the climatic periods described here. These environmental changes could be generalised for the whole of the Gulf of Guinea and possibly for the south Atlantic basin.

\section{Acknowledgements}

The financial assistance for this work provided by Orstom (now IRD) through a research grant to K.A. Koranteng, and the European Union through the INCO-DC Research and Technology for Development programme is gratefully acknowledged. Dr. Claude Roy provided invaluable assistance with the acquisition of the COADS data. We thank Dr. Claude Roy and Prof. Daniel Pauly for comments on an earlier version of the paper and also the reviewers for their constructive comments.

\section{REFERENCES}

Ansa-Emmim, M., 1979. Occurrence of the triggerfish, Balistes capriscus (Gmel), on the continental shelf of Ghana. Report of the special working group on the evaluation of demersal stocks of the Ivory Coast-Zaire sector, CECAF/ECAF SERIES/79/14 (En).. FAO, Rome, pp. 20-27.

Arfi, R., Pezennec, O., Cissoko, S., Mensah, M.A., 1991. Variations spatiale et temporelle de la résurgence ivoiro-ghanéenne. In: Cury, P., Roy, C. (Eds.), Variabilité, instabilité et changement dans les pêcheries ouest africaines. Orstom Éditions, Paris, pp. 162-172.

Baird, D., McGlade, J.M., Ulanowicz, R.E., 1991. The comparative ecology of six marine ecosystems. Philos. Trans. R. Soc. London Ser. B Biol. Sci. 333, 15-29.

Bakun, A., 1978. Guinea Current upwelling. Nature 271, 147-150.

Bakun, A., 1996. Patterns in the Ocean: ocean processes and marine population dynamics. University of California Sea Grant, San
Diego, CA, in cooperation with Centro de Investigaciones Biológicas de Noroeste, La Paz, Baja California Sur..

Bard, F.X., Koranteng, K.A., 1995. Dynamics and use of Sardinella resources from upwelling off Ghana and Ivory Coast. Orstom Éditions, Paris.

Binet, D., 1997. Climate and pelagic fisheries in the Canary and Guinea currents1964-1993: the role of trade winds and the southern oscillation. Oceanol. Acta 20, 177-190.

Binet, D., Marchal, E., 1993. The large marine ecosystem of the shelf areas in the Gulf of Guinea: long-term variability induced by climatic changes. In: Sherman, K., Alexander, L.M., Gold, B. (Eds.), Large marine ecosystems - stress, mitigation, and sustainability. American Association for the Advancement of Science, Boulder, CO, pp. 104-118.

Caverivière, A., 1991. L'explosion démographique du baliste (Balistes carolinensis) en Afrique de l'ouest et son évolution en relation avec les tendances climatiques. In: Cury, P., Roy, C. (Eds.), Variabilité, instabilité et changement dans les pêcheries ouest africaines. Orstom Éditions, Paris, pp. 354-367.

Chatfield, C., 1996. The analysis of time series, an introduction. Chapman and Hall Ltd, London.

Cleveland, R.B., Cleveland, W.S., McRae, J.E., Terpenning, I., 1990. STL: A seasonal-trend decomposition procedure based on Loess. J. Off. Stat. 6, 3-73.

FRU/Orstom, 1976. Rapport du groupe de travail sur la sardinelle (Sardinella aurita) des côtes ivoiro-ghanéennes. Orstom Éditions, Paris.

Hisard, P., 1988. El Niño response of the tropical Atlantic Ocean during the1984 year. In: Wyatt, T., Larrañeta, M.G. (Eds.), Proceedings of the International symposium on long term changes in marine fish populations, Vigo, Spain 1986. Consejo Superior de Investigaciones Cientificas, Madrid, pp. 273-290.

Houghton, R.W., 1986. Circulation and hydrographic structure over the Ghana continental shelf during the 1974 upwelling. J. Geophys. Res. 94 (4), 4816-4828.

Koranteng, K.A., 1984. A trawling survey off Ghana. CECAF/TECH/84/63, CECAF Project. FAO, Dakar.

Koranteng, K.A., 1998. The impacts of environmental forcing on the dynamics of demersal fishery resources of Ghana. Ph.D. Thesis. University of Warwick, Coventry.

Koranteng, K.A., Pezennec, O., 1998. Variability and trends in environmental time series along the Ivorian and Ghanaian Coasts. In: Durand, M.H., Cury, P., Mendelssohn, R., Roy, C., Bakun, A., Pauly, D. (Eds.), Global versus local changes in upwelling systems. Orstom Éditions, Paris, pp. 167-177.

Kraus, E.B., 1977. Subtropical droughts and cross-equatorial energy transports. Month. Weather Rev. 105, 1009-1018.

Longhurst, A.R., 1962. A review of the oceanography of the Gulf of Guinea. Bull. Inst. Fr. Afr. Noire Ser. A Sci. Nat. 24, 633-663.

Margalef, R., 1988. Reset successions and suspected chaos in models of marine populations. In: Wyatt, T., Larrañeta, M.G. (Eds.), Proceedings of the International symposium on long term changes in marine fish populations, Vigo, Spain 1986. Consejo Superior de Investigaciones Cientificas, Madrid, pp. 321-343. 
Marchal, E., Picaut, J., 1977. Répartition et abondance évaluées par échointégration des poissons du plateau continental ivoiro-ghanéen en relation avec les upwellings locaux. J. Rech. Océanogr. 2, 39-57.

MathSoft Inc., 1995. S-PLUS for Windows, Version 3.3 Release 1. MathSoft Inc., New York.

Mendelssohn, R., Cury, P., 1987. Fluctuations of a fortnightly abundance index of the Ivorian coastal pelagic species and associated environmental conditions. Can. J. Fish. Aquat. Sci. 44, 408-428.

Mendelssohn, R., Roy, C., 1996. Comprehensive ocean data extraction users guide, U.S. Dept. Comm., NOAA Tech. Memo. NOAA-TMNMFS-SWFSC-228. NOAA, La Jolla, CA.

Merle, J., 1978. Atlas hydrologique saisonnier de l'océan atlantique intertropical. Travaux et documents de l'Orstom, 82, Orstom Éditions, Paris.

Moore, D.W., Hisard, P., McCreary, J.P., Merle, J., O'Brien, J.J., Picaut, J., Verstraete, J.M., Wunsch, C., 1978. Equatorial adjustment in the eastern Atlantic Ocean. Geophys. Res. Lett. 5, 637-640.

Pezennec, O., 1994. Instabilité et changements de l'écosystème pélagique côtier ivoiro-ghanéen. Variabilité de la ressource en sardinelles: faits, hypothèses et théories, Thèse de doctorat, océanologie biologique. Université de Bretagne Occidentale, Brest.

Pezennec, O., Bard, F.X., 1992. Importance écologique de la petite saison d'upwelling ivoiro-ghanéenne et changements dans la pêcherie de Sardinella aurita. Aquat. Living Res. 5, 249-259.

Pezennec, O., Koranteng, K.A., 1998. Changes in the dynamics and biology of small pelagic fisheries off Côte d'Ivoire and Ghana - the ecological puzzle. In: Durand, M.H., Cury, P., Mendelssohn, R., Roy, C., Bakun, A., Pauly, D. (Eds.), Global versus local changes in upwelling systems. Orstom Éditions, Paris, pp. 329-343.

Pople, W., Mensah, M.A., 1971. Evaporation as the upwelling mechanism in Ghanaian coastal waters. Nat. Phys. Sci. 234, 18-20.

Quaatey, S.N.K., Maravelias, C.D., 1999. Maturity and spawning pattern of Sardinella aurita in relation to water temperature and zooplankton abundance off Ghana. West Africa. J. Appl. Ichthyol. $15,63-69$.

Roy, C., 1995. The Côte d'Ivoire and Ghana coastal upwellings dynamics and changes. In: Bard, F.X., Koranteng, K.A. (Eds.), Dynamics and use of sardinella resources from upwelling off Ghana and Ivory Coast. Orstom Éditions, Paris, pp. 346-361.

Servain, J., Picaut, J., Merle, J., 1982. Evidence of remote forcing in the equatorial Atlantic Ocean. J. Phys. Oceanogr. 12, 457-463.

Shannon, L.V., Boyd, A.J., Brundrit, G.B., Taunton-Clark, J., 1986. On the existence of an El Niño phenomenon in the Benguela system. J. Mar. Res. 44, 495-520.

Stromme, T., 1983. Final report of the R/V Dr. Fridtjof Nansen fish resource surveys off West Africa from Agadir to Ghana, CECAF/ECAF Series 84/29 (En). FAO, Rome.

Woodruff, S.D., Slutz, R.J., Jenne, R.L., Steurer, P.M., 1987. A comprehensive ocean-atmosphere data set. Bull. Am. Meteorolog. Soc. 68, 1239-1250. 